\title{
Statin-induced apoptosis of vascular endothelial cells is blocked by dexamethasone
}

\author{
C J Newton, G Ran, Y-X Xie, D Bilko, C H Burgoyne ${ }^{1}$, I Adams ${ }^{1}$, \\ A Abidia ${ }^{2}$, P T McCollum ${ }^{2}$ and S L Atkin ${ }^{1}$
}

\author{
Jacob's Well Medical Research Laboratory, Hull and York Medical School, Fenner Building, University of Hull, Cottingham Road, Hull HU6 7RX, UK \\ ${ }^{1}$ Diabetes and Endocrinology, Hull and York Medical School, University of Hull, Hull HU6 7RX, UK \\ ${ }^{2}$ Vascular Surgery, Hull and York Medical School, University of Hull, Hull HU6 7RX, UK \\ (Requests for offprints should be addressed to C Newton; Email: CJNewton@Compuserve.com)
}

\begin{abstract}
Statins block de novo synthesis of cholesterol by inhibiting the enzyme, HMG CoA reductase. The product of this reaction, mevalonic acid, is also a precursor of isoprenoids, molecules required for the activation of signalling G-proteins, such as Ras. Signal transduction pathways involving Ras are important for cell survival and this may be why statins induce apoptotic death of several cell types. Given that statins are used to treat vascular disease, it is surprising that no studies have been conducted on vascular endothelial cells. For this reason, we have tested the effect of fluvastatin (FS) on the endothelial cell line EA.hy 926. Here we show that FS, at concentrations from 1 to $2 \mu \mathrm{M}$, blocks growth and induces apoptosis of the endothelial cell line, EA.hy 926. As considerable redundancy exists in cell signalling pathways for cell survival, toxicity of FS under more physiological conditions might be prevented by pathways that do not require Ras, such as those activated by adrenal or sex steroids. To test this hypothesis, first RT-PCR analysis was performed for nuclear receptor mRNA expression. This revealed the presence of mRNA
\end{abstract}

for the androgen receptor (AR) and glucocorticoid receptor (GR). The effect of the AR agonist, dihydrotestosterone (DHT), and the GR agonist, dexamethasone (Dex), was then tested. Whilst DHT (100 nM) had no effect on FS-induced cell death, Dex $(1 \mu \mathrm{M})$ blocked FS-induced apoptosis. Cell cycle analysis revealed that $24 \mathrm{~h}$ exposure to FS prevented cells from leaving $G_{1}$ and $24-48 \mathrm{~h}$ later a marked sub- $G_{1}$ peak was observed. Dex was able to reduce the sub- $G_{1}$ peak, but it failed to reduce accumulation of cells in $G_{1}$. Further studies revealed that, in addition to blocking FS-induced apoptosis, Dex was able to block apoptosis of EA.hy 926 cells induced by serum deprivation, tumour necrosis factor- $\alpha$, oxidants, DNA damage and mitochondrial disruption. This study strongly suggests that glucocorticoids have a role to play in preventing vascular injury and they may provide a reason why statins are apparently not toxic to vascular endothelial cells in vivo.

Journal of Endocrinology (2002) 174, 7-16

\section{Introduction}

Statins are a class of compound that inhibit HMG-CoA reductase and result in the inhibition of cholesterol biosynthesis (Grundy 1998). Due to this property, statins are now one of the most widely used agents for the treatment of high cholesterol-related vascular disease (Gould et al. 1998). Several reports over the last 5 years have indicated that statins induce apoptosis of a number of cell types, including vascular smooth muscle cells (Stark et al. 1998, Buemi et al. 1999, Guijarro et al. 1999). To a large extent this may be explained by the fact that mevalonic acid, the product of the enzyme HMG-CoA reductase, is not only a precursor for cholesterol biosynthesis but is also a building block for isoprenoids (Edwards \& Ericsson 1999). As a component of one of the major cell signalling pathways, the small Ras G-protein is activated by iso- prenylation (Sinensky 2000) and isoprenylation inhibitors have been widely reported to induce apoptosis (Perez-Sala \& Mollinedo 1994). Indeed, the covalent modification of Ras is currently a major target in cancer drug development (Rowinsky et al. 1999, Perrin \& Hill 2000, Sebti \& Hamilton 2000). Recently, confirmation that the inhibition of Ras prenylation is the mechanism by which statins induce apoptotic cell death has come from studies on rat brain neuroblasts (Garcia-Roman et al. 2001). Here, it was shown that lovastatin-induced apoptosis was associated with a decrease in the expression of the anti-apoptotic proteins, Bcl-2 and Bcl- $\mathrm{x}_{\mathrm{L}}$ (Adams \& Cory 2001) and a decrease in the prenylation of $\mathrm{R}$ as. These effects were shown to be fully reversed by the addition of mevalonate.

A notable absence in the medical research literature is reference to articles on the effect of statins on vascular endothelial cells. For this reason the current report 
describes experiments where the effect of fluvastatin (Langtry \& Markham 1999) has been tested on immortalised human umbilical vein endothelial cells (HUVECs).

\section{Materials and Methods}

\section{Reagents}

All reagents for cell culture were obtained form Life Technologies (Paisley, Strathclyde, UK). Fluorescent probes for flow cytometry were obtained from Molecular Probes (Cambridge Bioscience, Cambridge, UK). Other flow cytometry reagents were obtained from Beckton Dickinson UK Ltd (Cowley, Oxfordshire, UK). The cell death ELISA was obtained from Roche Diagnostics Ltd (Lewes, E. Sussex, UK). Reagents for reverse transcription-polymerase chain reaction (RT-PCR) were obtained from Life Technologies and MWGAG Biotech (Ebersberg, Germany). Fluvastatin was provided as a gift from Novartis Ltd. All other reagents were obtained from Sigma-Aldrich Company Ltd (Poole, Dorset, UK). Mevalonic acid was added to the cells as the lactone (Sigma). In solution, mevalonic acid lactone spontaneously converts to mevalonic acid. Cholesterol was prepared from a stock ethanolic solution of $100 \mathrm{mM}$. This was then diluted to $2 \mathrm{mM}$ in Dulbecco's modified Eagle's medium (DMEM) prior to homogenisation with an Ultra-Turrax T25 and filtration with a $2-\mu \mathrm{m}$ sterile filter. Following this procedure, cholesterol determinations revealed that there was a $50 \%$ loss of cholesterol due to the filtration.

\section{Cell culture}

Cells of the line, EA.hy 926, originally derived from HUVECs (Claise et al. 1997), were maintained in DMEM with phenol red, penicillin $(50 \mathrm{U} / \mathrm{ml})$, streptomycin $(50 \mathrm{mg} / \mathrm{ml}$ ) and $10 \%$ fetal calf serum (FCS) (Life Sciences). For the majority of studies reported here, experiments were conducted on cells seeded into 48-well culture plates at densities over the range 2000 to 10000 cells per $\mathrm{cm}^{2}$. Cells were kept at $37^{\circ} \mathrm{C}$ in an atmosphere of $5 \%$ $\mathrm{CO}_{2}$ in air. For RT-PCR, flow cytometry experiments and caspase 3 assays, cells were harvested from $75-\mathrm{cm}^{2}$ culture flasks by the addition of trypsin/EDTA, centrifuged at $200 \mathrm{~g}$ and the cell pellet was either frozen immediately at $-80{ }^{\circ} \mathrm{C}$ for RT-PCR and caspase 3 activity or suspended in PBS for flow cytometry. For all experiments, cells were treated in medium containing 10\% FCS.

\section{Flow cytometry for cell cycle distribution}

Cell cycle analysis was performed on control and treated cells by the method of Ormerod (1998). In brief, a single cell suspension was prepared in $200 \mu \mathrm{l}$ PBS to which was added $2 \mathrm{ml}$ ice-cold, $70 \%$ ethanol. This suspension was then left for $30 \mathrm{~min}$ at $4{ }^{\circ} \mathrm{C}$. Cells were harvested by centrifugation at $200 \mathrm{~g}$ and were re-suspended in $800 \mu \mathrm{l}$ PBS. Propidium iodide (PI; $20 \mu \mathrm{l}, 0.5 \mathrm{mg} / \mathrm{ml}$ ) was then added and the labelled cells were kept at $37^{\circ} \mathrm{C}$ for $30 \mathrm{~min}$ before analysis with a FACS ${ }^{\text {CALIBUR }}$ (Becton-Dickinson UK Ltd) flow cytometer with an argon laser tuned to $488 \mathrm{~nm}$. Forward and orthogonal light scatter and red fluorescence (FL-2) were then determined and histogram plots were analysed for cell cycle distribution using the program ModFit (Becton-Dickinson).

\section{Determination of cell numbers and mode of cell death}

Cell numbers were directly determined using a Coulter Counter. Prior to measurement, cell monolayers (in 48-well culture plates) were washed with PBS before the addition of trypsin/EDTA $(400 \mu \mathrm{l})$. After $10 \mathrm{~min}$ at $37^{\circ} \mathrm{C}$, $50 \mu \mathrm{l}$ FCS were added and the detached cells were re-suspended in $20 \mathrm{ml}$ Isoton (Beckman-Coulter UK Ltd) prior to counting. An indirect estimate of live cell numbers was also made by the addition of $50 \mu \mathrm{l}$ of a $1 \mathrm{mg} / \mathrm{ml}$ solution (in PBS) of the diazo salt 3-[4,5-dimethylthiazol2-yl]-2,5-diphenyltetrazolium bromide (MTT). After $4 \mathrm{~h}$, the blue crystals were solubilised by the addition of sodium dodecyl sulphate in $\mathrm{HCl}$ at final concentrations of $10 \%$ and $10 \mathrm{mM}$ respectively as previously described (Newton et al. 1995).

The mode of cell death was determined by normal light and fluorescence microscopy in combination with the measurement of biochemical indicators of apoptosis. Microscopic analysis was made using a Leica DMIL fitted with a SPOT ${ }^{\mathrm{JUNIO}}$ digital camera (Diagnostic Instruments, CA, USA), using a combination of Image Modulation Contrast for normal light and u.v. exposure $(380 \mathrm{~nm})$ with a wide band pass filter for fluorescence. Photo-quality pictures were produced with a Hewlett Packard 970 Cxi and Kodak Premium paper. The integrity of cell membranes was determined under u.v. light following the addition of a mixture of PI and Hoechst 33342 to give final concentrations of $10 \mu \mathrm{g} / \mathrm{ml}$ and $1 \mu \mathrm{g} / \mathrm{ml}$ respectively. Cells with disrupted membranes gave red nuclear fluorescence due to the uptake of PI, whilst cells with intact membranes gave blue nuclear fluorescence.

The mode of cell death was further characterised by determining caspase 3 activity with the ApoAlert colorimetric assay kit from Clontech Labs (Palo Alto, CA, USA) and fragmentation of DNA with an ELISA (Roche Diagnostics Ltd) that we have previously shown to be specific for the detection of DNA fragmentation that occurs in apoptosis (Newton et al. 1999).

\section{RT-PCR protocol}

RNA extraction and cDNA synthesis were performed as previously described (Speirs et al. 1997). Substitution of 

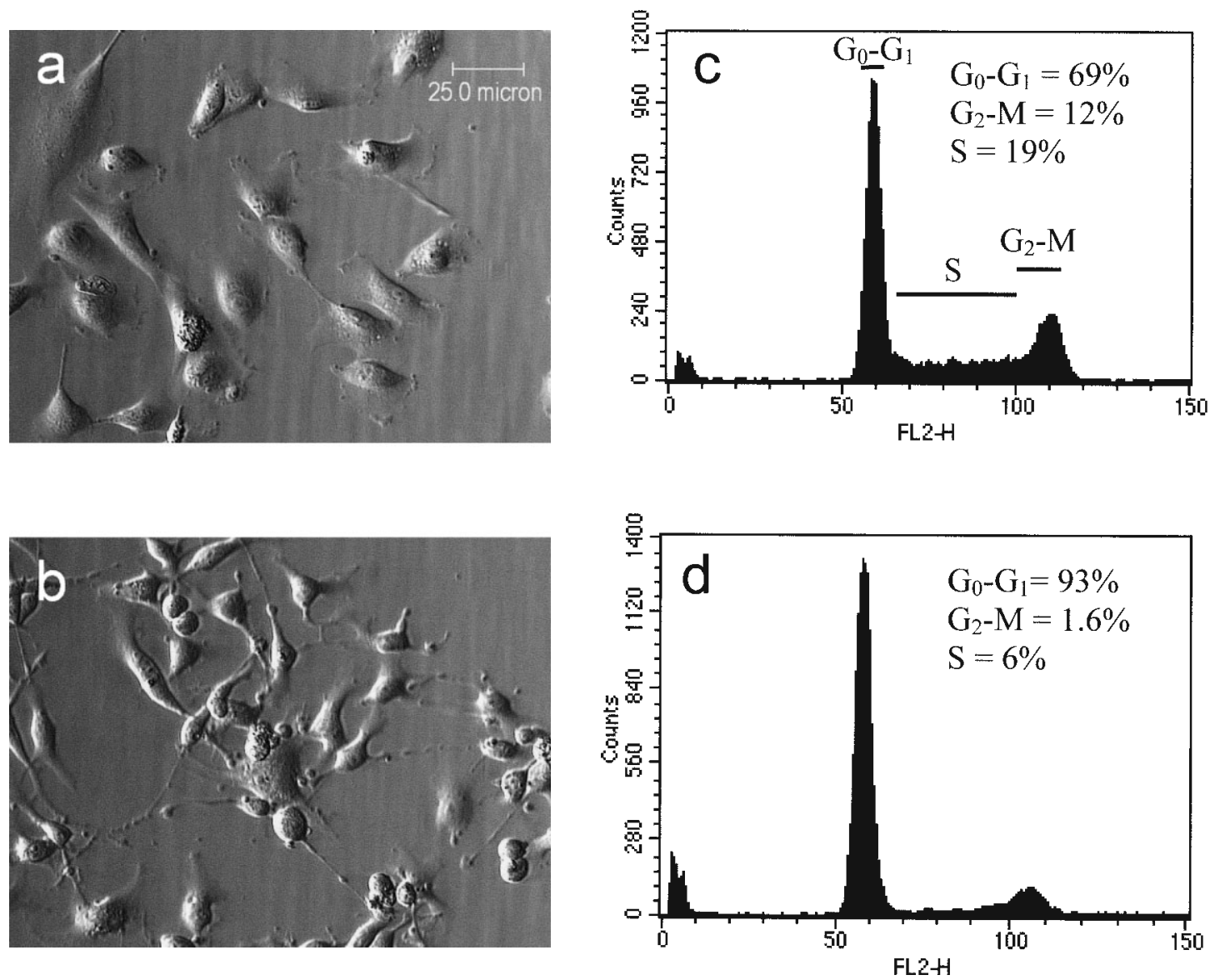

Figure 1 Response of low density EA.hy 926 endothelial cells to 24-h exposure to $10 \mu \mathrm{M} \mathrm{FS}$ (b and d) in comparison with control, untreated cells ( $a$ and $c$ ), shown as image modulate contrast microscopy $(\times 200$, a and b) and flow cytometry (c and d).

reverse transcriptase with distilled water served as a control to ensure that RNA, rather than genomic DNA, was being extracted and subsequently amplified. In further experiments, this control was uniformly negative.

Primers for PCR of the androgen receptor (AR), glucocorticoid receptor (GR), progesterone receptor (PR), oestrogen receptor alpha $(\mathrm{ER} \alpha)$, and oestrogen receptor beta $(\operatorname{ER} \beta)$ were designed from published gene sequences and were synthesised by Life Technologies and MWG Biotech. To check the integrity of the cDNA, fragments of glyceraldehyde-3-phosphate dehydrogenase (GAPDH) or pyruvate dehydrogenase (PDH), standard housekeeping genes, were amplified in parallel. The PCR reaction comprised 2 units of BIOTAQ, $10 \times$ PCR buffer (Bioline, London, UK), $1.5 \mathrm{mM} \mathrm{MgCl} 2,0.5 \mu \mathrm{g}$ of each oligonucleotide primer, $200 \mu \mathrm{M}$ each of dATP, dCTP, dGTP and dTTP, $1 \mu \mathrm{l}$ nascent cDNA and sterile distilled water to bring the volume to $50 \mu \mathrm{l}$. Appropriate positive and negative controls were set-up in parallel. Negative controls included substitution of RNA or cDNA with distilled water, or substitution of cDNA with an irrelevant cDNA (human tibialis anterior muscle). Transcripts were analysed in parallel in a thermal cycler (Hybaid OmniGene, Teddington, UK) with the following cycle: a denaturation step at $94{ }^{\circ} \mathrm{C}$ for $2 \mathrm{~min}$, followed by 35 cycles of $94^{\circ} \mathrm{C}$ for $30 \mathrm{~s}$ (denaturing), $55^{\circ} \mathrm{C}$ for $30 \mathrm{~s}$ (annealing), $72{ }^{\circ} \mathrm{C}$ for $30 \mathrm{~s}$ (extension) and a final primer extension step of $72{ }^{\circ} \mathrm{C}$ for $5 \mathrm{~min}$. PCR for $\mathrm{ER} \beta$ used an alternative annealing temperature of $58{ }^{\circ} \mathrm{C}$. PCR products were analysed by electrophoresis through a $1 \cdot 2 \%$ or $1.5 \%$ agarose gel and visualised by ethidium bromide staining under u.v. light.

Restriction digests were performed on representative PCR products to confirm their identity. Five microlitres of the amplified product were digested with the appropriate restriction enzyme for $2 \mathrm{~h}$ at $37^{\circ} \mathrm{C}$. The digested products were then electrophoresed through a $2 \%$ agarose gel and visualised as described above. 

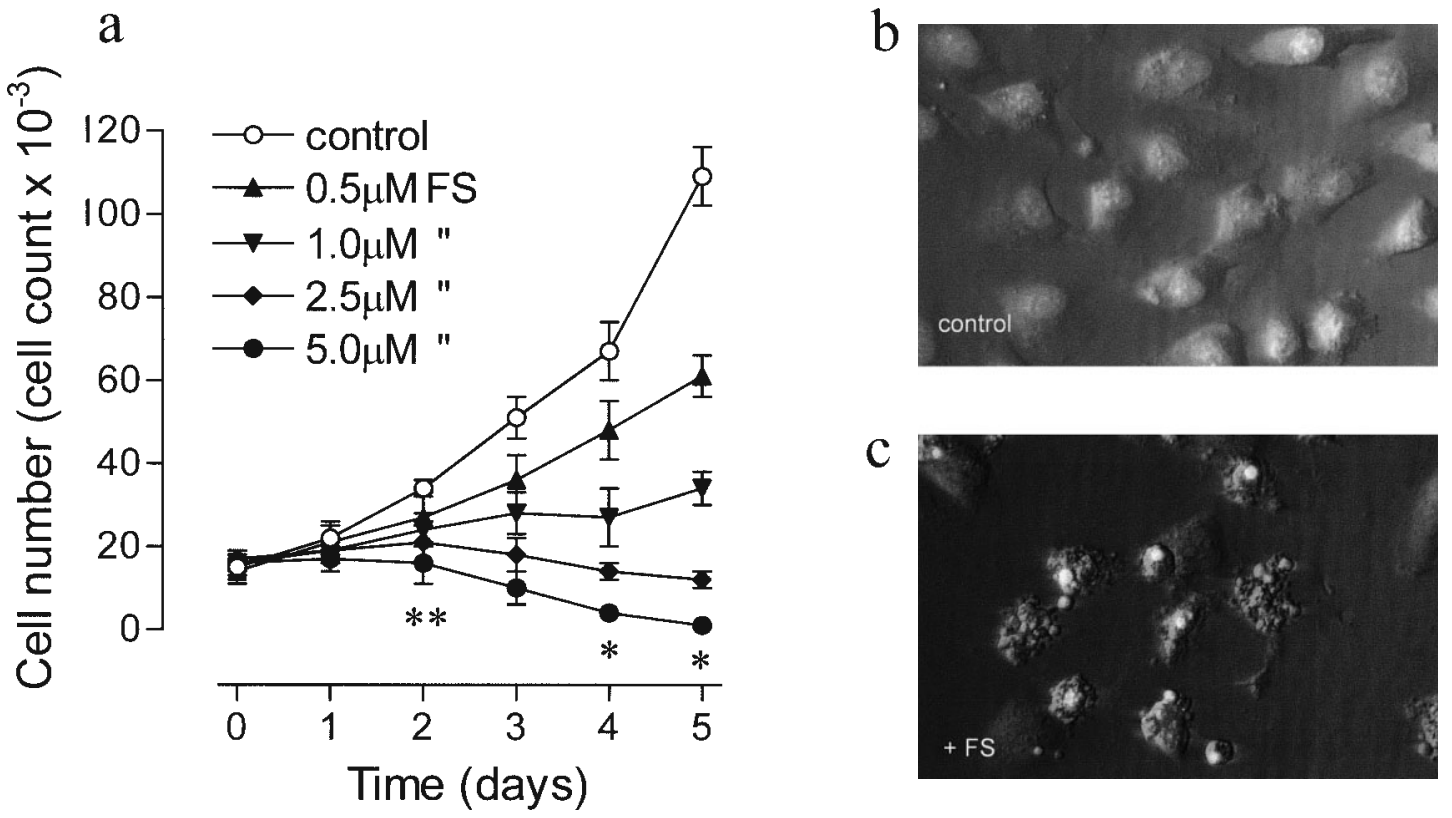

Figure 2 (a) The growth curve for endothelial cells exposed to a dose range of FS. Normal light and fluorescent microscopy $(\times 400)$ for control cells and cells exposed to $10 \mu \mathrm{M}$ FS for $72 \mathrm{~h}$ is shown in (b) and (c) respectively. All values in this and the following figures are given as means \pm S.D. ${ }^{*} P<0 \cdot 05$, day 4 and $5,5 \mu \mathrm{M}$ FS compared with zero time cell numbers; ${ }^{*} P<0 \cdot 01$, day $2,5 \mu \mathrm{M}$ FS compared with control.

\section{Statistics}

Statistical analysis was performed on a minimum of three replicates using ANOVA, but in some cases figures are only marked with significance values where a particular aspect of the work requires emphasis. With the exception of Table 1, where values are a composite from three identical experiments, all figures are reproduced as representative experiments from at least five studies. All values given in the figures are expressed as means \pm S.D.

\section{Results}

\section{Cell cycle effects of short-term exposure to fluvastatin (FS)}

Following a 24-h exposure of cells at a density of around $25000 / \mathrm{cm}^{2}$ to $10 \mu \mathrm{M}$ FS, microscopic observation of cells revealed a rounding of the cell body with many cells showing filamentous projections as indicated in Fig. 1b compared with untreated cells (Fig. 1a). Cells similarly treated with FS for $24 \mathrm{~h}$ in $75-\mathrm{cm}^{2}$ flasks were subjected to flow cytometry analysis after fixing and labelling nuclei with PI as described in Materials and Methods. The corresponding histogram profiles for one of three experiments following cell cycle distribution analysis are shown in Fig. 1c and d. The insets on (c) and (d) give the combined statistics for all three experiments. This analysis reveals that the proportion of cells in $G_{0}-G_{1}$ increased from $69 \pm 8 \%$ for control untreated cells to $93 \pm 6 \%$ for cells treated with $10 \mu \mathrm{M}$ FS (control vs FS, $P<0 \cdot 01$ ). In parallel, the number of cells in $\mathrm{G}_{2}-\mathrm{M}$ and $\mathrm{S}$ phases decreased from $12 \pm 5 \%$ and $19 \pm 6 \%$ respectively for controls to $1 \cdot 6 \pm 0 \cdot 8 \%$ and $6 \pm 6 \%$ for cells treated with FS (control vs treatment; $\mathrm{G}_{2}-\mathrm{M}, P<0 \cdot 01$ and $\mathrm{S}$ phase, $\left.P<0 \cdot 05\right)$. These observations strongly suggest that FS prevented cells from leaving the $G_{1}$ phase, allowing accumulation in this phase of the cell cycle.

\section{Long-term response of EA.hy 926 cells to FS}

To determine how the apparent cell cycle blockade imposed by FS affected cell numbers, the dose-response to FS was monitored over a 5-day treatment period. Figure 2 a shows that at $5 \mu \mathrm{M}$ FS, cell numbers were significantly lower $(P<0 \cdot 01)$ than the corresponding controls after $48 \mathrm{~h}$ of treatment. By day 3, there was widespread appearance of cells with numerous small blebs as shown in Fig. 2c. Some of these contained blue fluorescent fragments indicating that nuclear fragmentation had occurred, a classical sign of apoptosis. This response is quite distinct from necrosis, as nuclear fragmentation is never a hallmark of the necrotic process. Therefore, cell numbers after 4 days of treatment with $5 \mu \mathrm{M}$ FS had fallen significantly below the pretreatment values $(P<0 \cdot 05)$ due to the loss of cells by apoptosis. By visual observation under u.v. and normal light, Fig. 3 shows the proportion of the cell population with apoptotic nuclei from an experiment where cells 


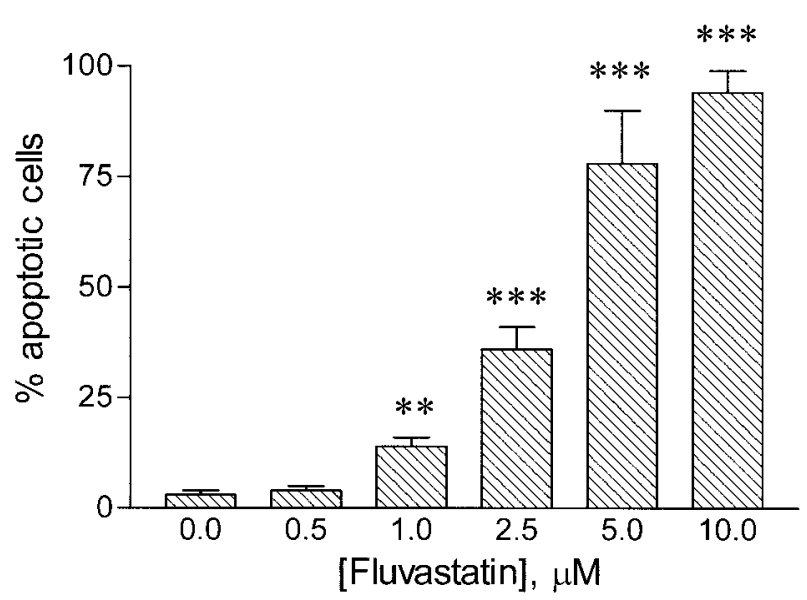

Figure 3 Response of cells to a dose range of FS (72-h treatment) measured as the proportion of apoptotic cells determined after addition of Hoechst 33342 and $\mathrm{Pl} .{ }^{*} P<0 \cdot 01,{ }^{* * *} P<0 \cdot 001$ compared with control.

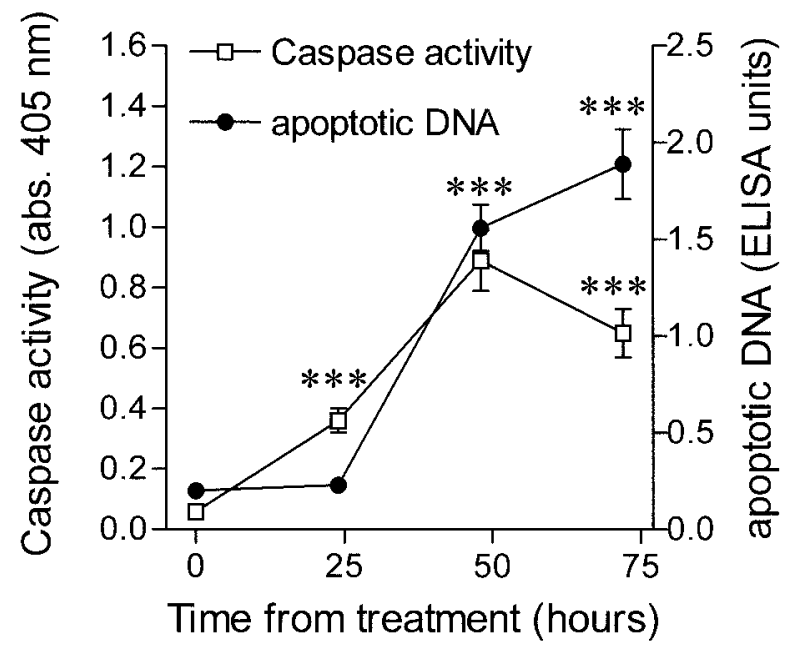

Figure 4 Time course for the activation of caspase 3 and the appearance of DNA fragments in response to treatment of cells with $5 \mu \mathrm{M}$ FS. ${ }^{* * *} P<0 \cdot 001$ compared with control. abs, absorbance.

were treated with a dose range of FS. After 72-h exposure to FS, a significant increase $(P<0 \cdot 01)$ in the proportion of the population undergoing apoptosis was observed from $1 \mu \mathrm{M}$ with a maximum response observed at around $5 \mu \mathrm{M}$. It should be noted that necrosis was never observed in any experiment with FS.

\section{Biochemical parameters of cell death in response to FS}

Over a time course of $72 \mathrm{~h}$, caspase activity and DNA fragmentation was measured after exposure to $5 \mu \mathrm{M}$ FS. Figure 4 shows that a significant $(P<0 \cdot 001)$ rise in caspase 3 activity was noted after $24-\mathrm{h}$ exposure to $5 \mu \mathrm{M}$ FS. In contrast, DNA fragmentation measured with the ELISA was not observed to rise significantly above control values until the 48-h time point of exposure.

Cellular response to FS in combination with products of the HMG-CoA pathway

To determine the specificity of the response to FS for inhibition of HMG-CoA reductase, experiments were performed where FS was combined with mevalonic acid and also with cholesterol over a dose range of 5 to $50 \mu \mathrm{M}$. Over a time period of 72-h treatment, mevalonic acid completely blocked the FS-induced loss of cellular metabolic activity measured by the addition of the diazo dye, MTT (Fig. 5a). As the end product of the HMG-CoA pathway, the effect of cholesterol was also determined. Over the dose range 0.5 to $2 \mu \mathrm{M}$ FS and with cholesterol at final concentrations of $5,10,25$ and $50 \mu \mathrm{M}$, the effect on cellular metabolic activity was determined after 72-h exposure. Figure $5 \mathrm{~b}$ shows that, in contrast to mevalonic acid, cholesterol at concentrations of $10 \mu \mathrm{M}$ and above significantly enhanced $(P<0 \cdot 001)$ the response to FS.

\section{The effect of the endocrine environment on response to FS}

Prior to exposure to a dose range of various steroid hormones, the expression of receptor mRNA was determined by RT-PCR with selected primer sequences for ER $\alpha, E R \beta, P R, A R$ and GR. Figure 6 shows that both the $A R$ and the GR were expressed in these EA.hy 926 endothelial cells. Experiments were then conducted on the dose-response to FS in the presence of both the GR agonist, dexamethasone (Dex), and the AR agonist, dihydrotestosterone (DHT), compounds shown to fully transcriptionally activate the receptors (Newton et al. 2001). Prior to treatment with FS, cells were pretreated for $24 \mathrm{~h}$ with $100 \mathrm{nM}$ DHT or $1 \mu \mathrm{M}$ Dex. After a further 72-h exposure to a dose range of FS, DNA fragmentation was measured by ELISA. Whilst DHT had no effect on the response to FS, Dex completely blocked the ability of FS to induce DNA fragmentation (Fig. 7). For high density cells exposed to FS for $72 \mathrm{~h}$ in combination with a dose range of Dex $(1 \mathrm{nM}-1 \mu \mathrm{M})$, Fig. $7 \mathrm{~b}$ shows the light microscope appearance of cells. Clear apoptotic morphology is observed in the presence of FS and low concentrations of Dex $(1 \mathrm{nM})$ and this is progressively blocked as the concentration of Dex is increased. It should be noted from Fig. $7 \mathrm{~b}$ that even at $1 \mu \mathrm{M}$, Dex failed to block the FS-induced change in cell morphology.

Further analysis by flow cytometry of the effect of Dex on the cell cycle distribution in response to 48-h and 72-h exposure to FS $(5 \mu \mathrm{M})$ revealed that at $48 \mathrm{~h}$ there was a substantial sub- $G_{1}$ peak with FS alone and that this was absent in the presence of Dex $(1 \mu \mathrm{M})$ (Fig. 8). In contrast to the profile for untreated cells, cells still appeared to be accumulating in the $G_{1}$ phase when treated with FS and 
a

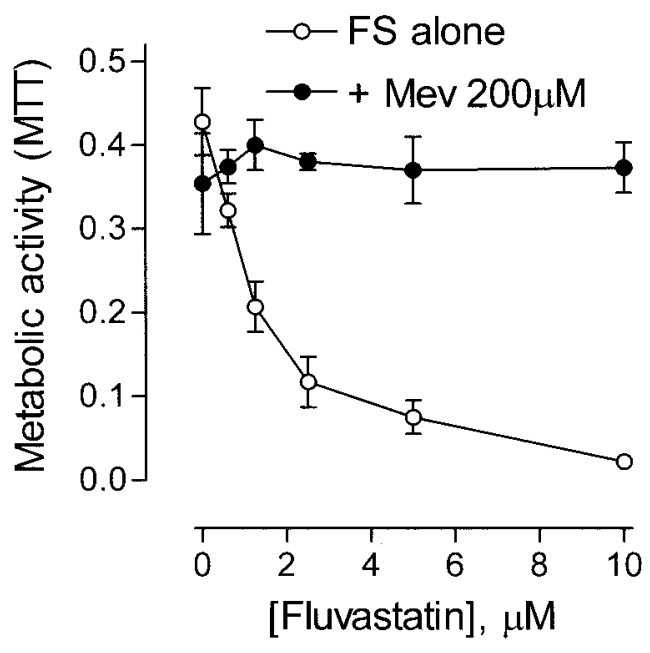

b
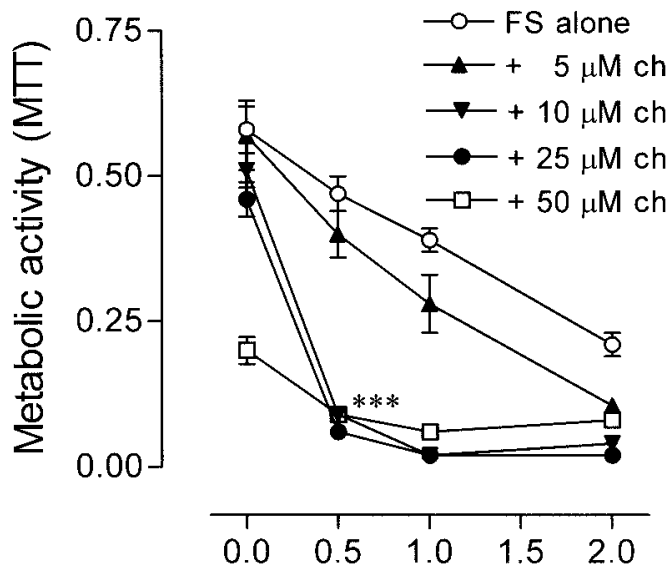

[Fluvastatin], $\mu \mathrm{M}$

Figure 5 (a) Reversal of the effect of FS $(5 \mu \mathrm{M})$ by the inclusion of mevalonic acid lactone (Mev, $200 \mu \mathrm{M})$. (b) The enhancement of low dose FS-induced loss of cellular metabolic activity (MTT absorbance, $540 \mathrm{~nm}$ ) by the inclusion of cholesterol $(\mathrm{ch})$ in the culture media. ${ }^{* *} P<0 \cdot 001$ compared with FS alone.

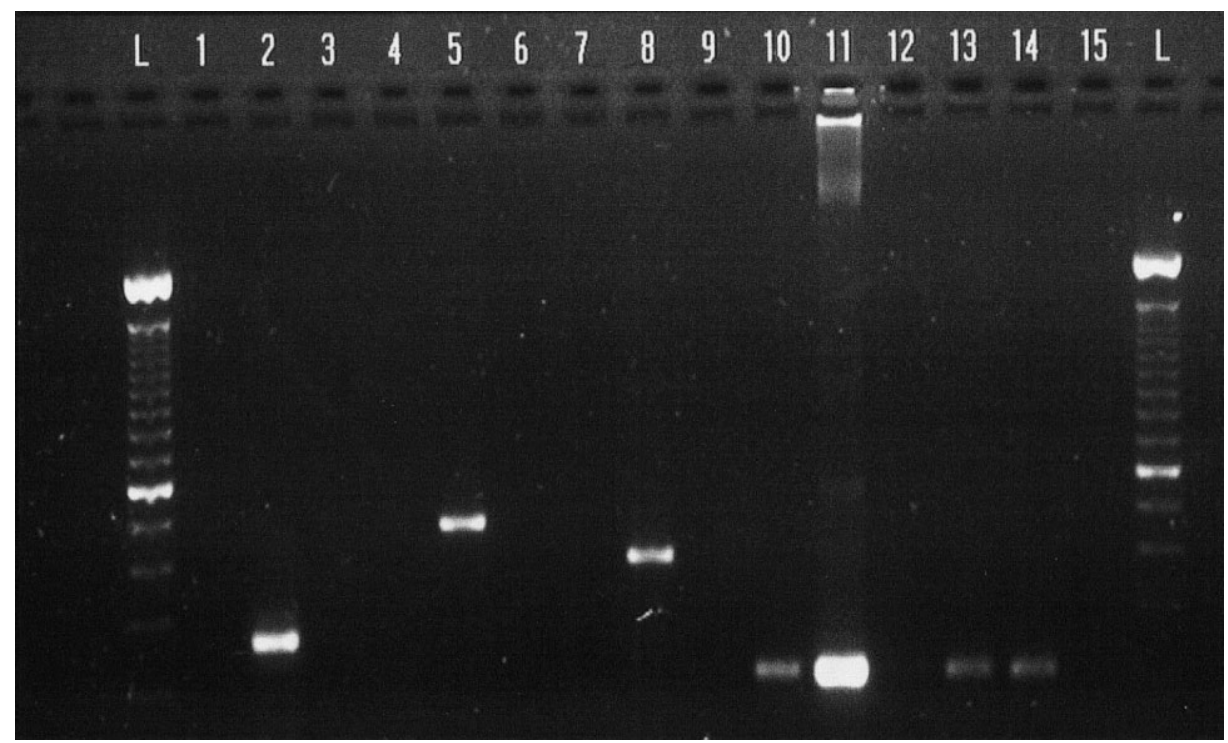

Figure 6 RT-PCR analysis for the expression of ER $\alpha, E R \beta, P R, A R$ and GR within EA.hy 926 vascular endothelial cells. L,100 bp ladder; 1, EA.hy ER $\alpha$; 2, ER $\alpha$ +ve control; 3, ER $\alpha$ - ve control; 4, EA.hy ER $\beta$; 5, ER $\beta$ +ve control; 6, ER $\beta$ - ve control; 7, EA.hy PR; 8, PR +ve control; 9, PR - ve control; 10, EA.hy AR; 11, AR +ve control; 12, AR - ve control; 13, EA.hy GR; 14, GR +ve control; 15, GR - ve control.

Dex. Over three experiments, the proportion of the cell population in the various phases of the cell cycle is given in Table 1. From this Table it is clear that Dex significantly $(P<0 \cdot 01)$ prevents the appearance of sub- $G_{1}$ nuclei with a reduced DNA content. It is also apparent that in comparison with the controls, there are still significantly fewer cells in $\mathrm{S}$ and $\mathrm{G}_{2}-\mathrm{M}$ after treatment with both FS and Dex.
After a further 24-h exposure to FS, the majority of cells were sub- $G_{1}$ and Dex was still capable of providing some protection against FS-induced apoptosis (Fig. 8). It should also be pointed out that when added alone, Dex failed to change cell cycle parameters (Fig. 8) and although data are not shown, this was reflected by an inability of Dex to alter cell numbers over a period of 5 days from first treatment. 
a

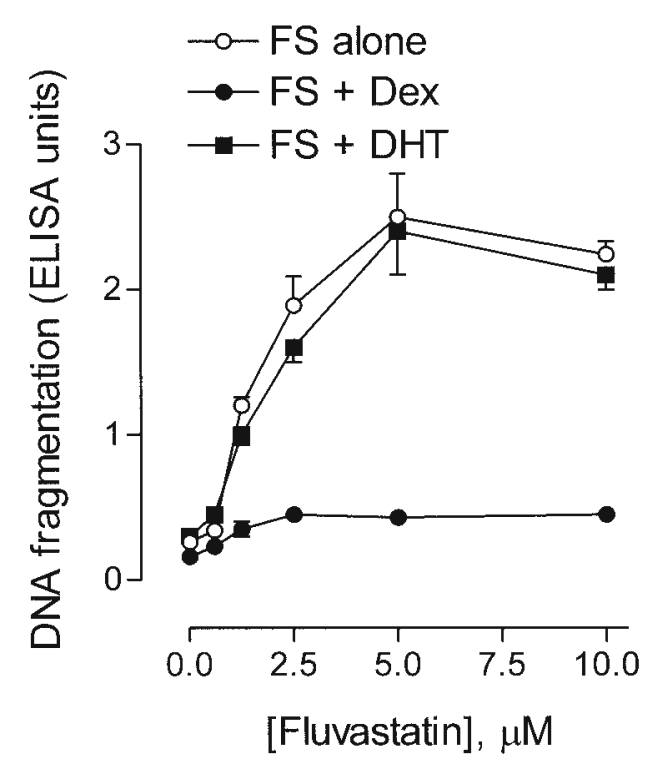

b
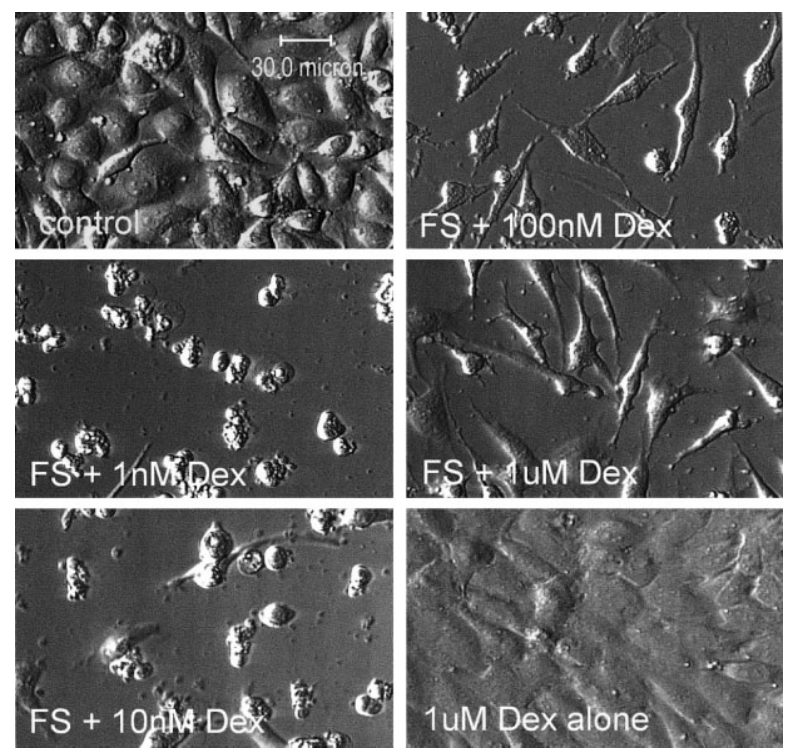

Figure 7 (a) Response of high-density endothelial cells to a dose range of FS (72-h exposure) in the presence of the androgen, DHT $(100 \mathrm{nM})$ and the glucocorticoid, Dex $(1 \mu \mathrm{M})$. (b) Image modulate contrast microscopy pictures $(\times 200)$ of cells exposed to FS $(5 \mu \mathrm{M})$ and a dose range of Dex.

\section{Dex response with other inducers of apoptosis}

To test whether Dex blocked the apoptotic pathway within these endothelial cells, the effect of Dex on several agents known to induce apoptosis through different cellular targets was tested. Table 2 shows that Dex $(1 \mu \mathrm{M})$ prevented an increase in DNA fragmentation and an increase in the proportion of the cell population with apoptotic nuclei in response to all agents tested.

\section{Discussion}

Considering that statins are one of the most widely used classes of cholesterol lowering agents, an omission in the medical research literature would appear to be studies addressed to the effect of statins on vascular endothelial cells. We now show in this paper that statins are toxic to endothelial cells derived from the human umbilical vein. It should be noted that although a cell line derived from HUVECs has been used for the studies presented here, FS was also toxic to primary HUVEC cultures. These studies are therefore consistent with the growing number of reports indicating that statins are toxic to a range of cell types (Stark et al. 1998, Buemi et al. 1999, Guijarro et al. 1999).

The current study concurs with other reports showing that statins prevent cells from entering $S$ phase of the cell cycle (Wu \& Gilbert 2000). As a consequence of this effect on cell cycle or by a mechanism involving the blockade of survival pathways, apoptotic cell death follows later. The ability of FS to induce apoptosis has been confirmed by the morphological appearance of cells, the presence of a sub- $G_{1}$ peak, induction of caspase 3 activity and the presence of extensive DNA fragmentation. The belief that FS causes these dramatic changes by interfering with the HMG-CoA pathway is confirmed by our observation showing that the product of HMG-CoA, mevalonic acid, completely reverses the effect of FS. As cholesterol, the final product of the HMG-CoA pathway, is unable to prevent FS-induced cell death, it is highly likely that blockade of the pathway of isoprenylation (Garcia-Roman et al. 2001) is the mechanism by which FS induces cell death.

It is significant that (as shown using flow cytometry) the glucocorticoid, Dex, is only able to block apoptosis, unlike mevalonic acid which blocks apoptosis and restores growth. This finding is clearly demonstrated in Fig. 8 and Table 1 where, particularly for 48 -h exposure to FS, the accumulation of sub- $G_{1}$ cells is blocked by Dex, but there are still very few cells entering $S$ and $G_{2}$. Therefore, it would appear that the action of Dex is not specific to modulating the effect of statin on the cell cycle, rather it would seem that Dex blocks endothelial cell apoptosis. This finding is consistent with some of the recent literature including our own (Newton et al. 2001) that glucocorticoids block apoptosis in other cell systems (Messmer et al. 2001, Mikosz et al. 2001, Sasson et al. 2001, Zhang et al. 2001). Table 2 provides data that strongly support the idea 

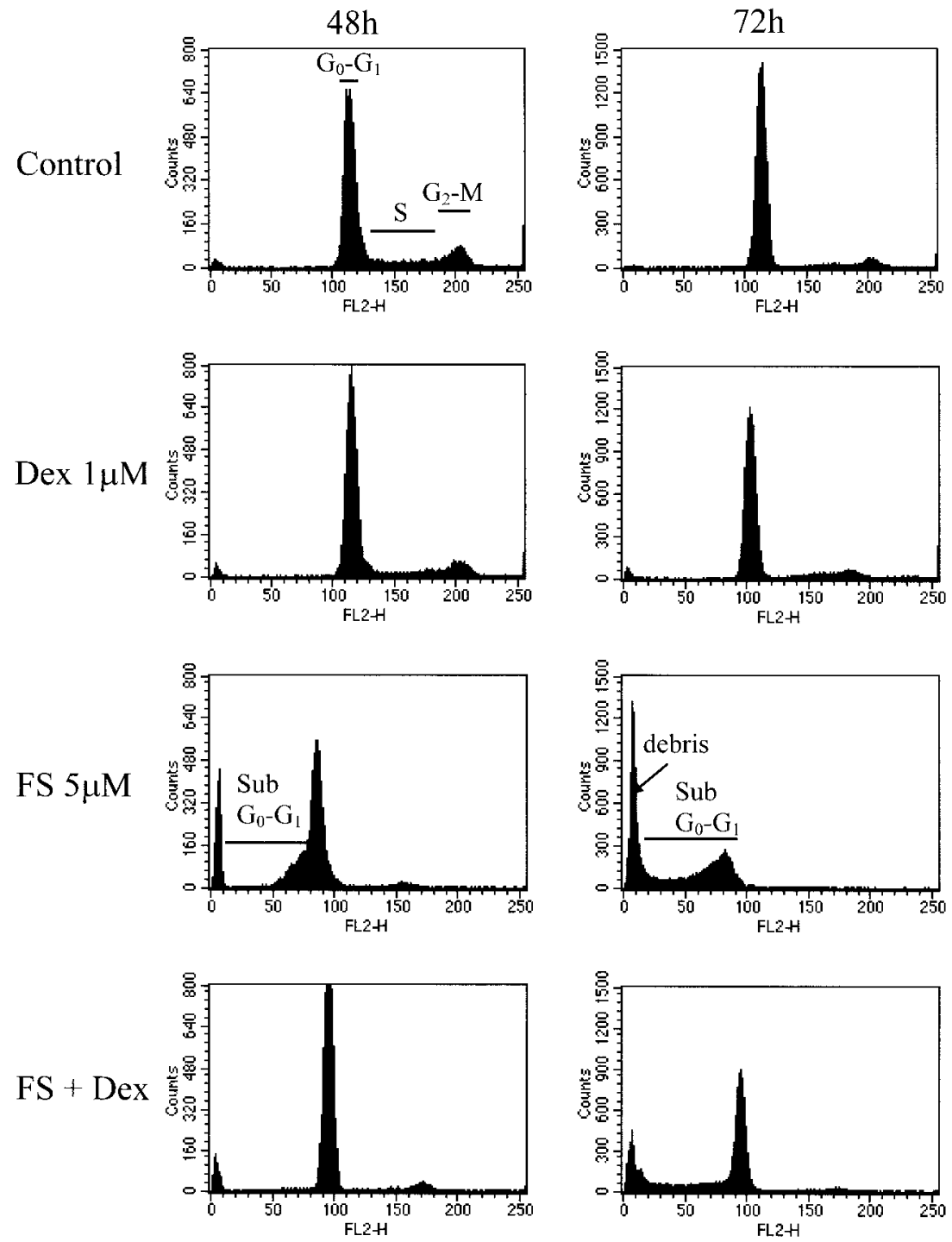

Figure 8 Flow cytometry profiles for cells exposed for 48 and $72 \mathrm{~h}$ to FS ( $5 \mu \mathrm{M})$ alone and in combination with Dex $(1 \mu \mathrm{M})$.

that the effect of Dex is to block apoptosis at a common element in the pathway. These agents were chosen to cover a range of cellular targets, from signal transduction pathways (serum withdrawal, tumour necrosis factor- $\alpha$ $(\mathrm{TNF} \alpha)$ ), to DNA damage with the topoisomerase 1 inhibitor, camptothecin. Of particular note are the observations with the protonophore carbonyl cyanide m-chlorophenylhydrazone, a compound that collapses the mitochondrial membrane potential (Newton et al. 2001), and with hexadecyl triphenyl phosphonium bromide, a compound that also targets mitochondria (unpublished observations, Newton CJ). By collapsing the membrane potential, both agents would be expected to result in the release of cytochrome $\mathrm{c}$ and the activation of the Apaf-1 complex of the apoptotic pathway (Zou et al. 1999). This strongly suggests that Dex blocks apoptosis down-stream of changes in mitochondrial function. Based on these findings, studies are being conducted to determine the precise point in the apoptotic pathway that is disrupted by Dex.

The past 5 years have seen a high degree of interest in the effect of oestrogens on the vasculature (Linder et al. 1998, Makela et al. 1999, Scheidegger et al. 2000, Andersson et al. 2001). This is now the first report to indicate that glucocorticoids are effective antiapoptotic agents for vascular endothelial cells. Using powerful, new quantitative PCR techniques, we are now showing the low level expression of the ER $\beta$ in these endothelial cells. Despite this, we have been unable to demonstrate a direct 
Table 1 Combined data from three flow cytometry experiments, where cells were exposed for $48 \mathrm{~h}$ to FS $(5 \mu \mathrm{M})$ alone and in combination with the glucocorticoid, Dex $(1 \mu \mathrm{M})$. All values for cell cycle phase, calculated by ModFit as percentage of the total number of sampled cells, are expressed as means \pm S.D.

\begin{tabular}{|c|c|c|c|c|}
\hline & Control & Dex & FS & FS + Dex \\
\hline \multicolumn{5}{|l|}{ Cell cycle phase } \\
\hline Sub $G_{1}$ & $1 \cdot 2 \pm 0 \cdot 9$ & $2 \cdot 3 \pm 1 \cdot 3$ & $39 \pm 12^{\star \star *}$ & $7 \pm 4^{+++}$ \\
\hline $\mathrm{G}_{0}-\mathrm{G}_{1}$ & $73 \pm 7$ & $85 \pm 7$ & $56 \pm 7^{*}$ & $88 \pm 4$ \\
\hline S & $15 \pm 4$ & $11 \pm 3$ & $3 \cdot 5 \pm 1 \cdot 3^{* *}$ & $2 \cdot 9 \pm 1 \cdot 5^{* *}$ \\
\hline $\mathrm{G}_{2}-\mathrm{M}$ & $11 \pm 4$ & $9 \pm 4$ & $1 \cdot 2 \pm 1 \cdot 7^{\star *}$ & $3 \cdot 1 \pm 2 \cdot 3^{*}$ \\
\hline
\end{tabular}

${ }^{*} P<0 \cdot 05,{ }^{* *} P<0 \cdot 01,{ }^{* * *} P<0 \cdot 001$ compared with control; ${ }^{++} P<0 \cdot 01$ compared with FS.

Table 2 The response of EA.hy 926 cells to a range of known inducers of apoptosis in the absence and presence of $1 \mu \mathrm{M}$ Dex. With the exception of serum withdrawal, where cells remained without serum for 4 days prior to assay, the other agents were added to cells for $24 \mathrm{~h}$ prior to assay. Values are means \pm S.D.

\begin{tabular}{|c|c|c|c|c|}
\hline \multicolumn{3}{|c|}{ DNA fragmentation (ELISA units) } & \multicolumn{2}{|c|}{ \% Apoptosis } \\
\hline Control & Statin & Statin + Dex & Statin & Statin + Dex \\
\hline $0 \cdot 29 \pm 0 \cdot 05$ & $1 \cdot 78 \pm 0 \cdot 21$ & $0 \cdot 35 \pm 0 \cdot 12^{*}$ & $29 \pm 7$ & $2 \pm 2^{*}$ \\
\hline $0 \cdot 29 \pm 0 \cdot 11$ & $0.98 \pm 0.08$ & $0 \cdot 25 \pm 0 \cdot 09^{*}$ & $12 \pm 3$ & $2 \pm 1^{*}$ \\
\hline $0 \cdot 31 \pm 0 \cdot 07$ & $2 \cdot 37 \pm 0 \cdot 18$ & $0 \cdot 46 \pm 0 \cdot 13^{*}$ & $34 \pm 6$ & $7 \pm 3^{*}$ \\
\hline $0 \cdot 27 \pm 0.05$ & $2 \cdot 37 \pm 0 \cdot 31$ & $0 \cdot 34 \pm 0 \cdot 04^{*}$ & $49 \pm 7$ & $9 \pm 4^{*}$ \\
\hline $0 \cdot 31 \pm 0 \cdot 14$ & $2 \cdot 46 \pm 0 \cdot 21$ & $0.52 \pm 0.03 *$ & $41 \pm 6$ & $7 \pm 3^{*}$ \\
\hline $0 \cdot 36 \pm 0.05$ & $2 \cdot 27 \pm 0 \cdot 19$ & $0 \cdot 41 \pm 0 \cdot 10^{*}$ & $43 \pm 4$ & $5 \pm 2^{*}$ \\
\hline
\end{tabular}

\section{Apoptosis inducer}

Serum withdrawal

$\mathrm{TNF} \alpha(100 \mathrm{ng} / \mathrm{ml})$

$\mathrm{H}_{2} \mathrm{O}_{2}(400 \mu \mathrm{M})$

Camptothecin $(1 \mu \mathrm{M})$

$\operatorname{mCICCP}(100 \mu \mathrm{M})$

$\operatorname{HDTP}(5 \mu \mathrm{M})$

\section{DNA fragmentation (ELISA units)}

mCICCP, carbonyl cyanide m-chlorophenylhydrazone; HDTP, hexadecyl triphenyl phosphonium bromide. ${ }^{\star} P<0.001$ compared with statin alone. antiapoptotic effect of a range of oestrogens on these vascular endothelial cells. This finding raises the possibility that in vitro it is the glucocorticoid, cortisol, that protects vascular endothelial cells against apoptosis induced by oxidised low density lipoprotein (Claise et al. 1997) and other toxic agents such as TNFa. In addition to this potential new physiological significance of glucocorticoids, these hormones may also provide a 'fail safe mechanism', whereby vascular endothelial cells are protected against the toxic side effects of statins, agents shown clinically to lower circulating cholesterol concentrations and to improve vascular function.

\section{Acknowledgements}

The authors would like to thank Yorkshire Cancer Research, and Hull and East Riding Charitable Trust for their support during this study.

\section{References}

Adams JM \& Cory S 2001 Life-or-death decisions by the Bcl-2 protein family. Trends in Biochemical Sciences 6 61-66.
Andersson C, Lydrup ML, Ferno M, Idvall I, Gustafsson J \& Nilsson BO 2001 Immunohistochemical demonstration of oestrogen receptor beta in blood vessels of female rat. Journal of Endocrinology $169241-247$.

Buemi M, Allegra A, Senatore M, Marino D, Medici MA, Aloisi C, Di Pasquale G \& Corica F 1999 Pro-apoptotic effect of fluvastatin on human smooth muscle cells. European Journal of Pharmacology 9 201-203.

Claise C, Chalas J, Edeas M, Abella A, Khalfoun Y, Laurent D \& Lindenbaum A 1997 Comparison of oxidized low density lipoprotein toxicity on EA.hy 926 cells and human vein endothelial cells: influence of antioxidant systems. Cellular and Molecular Life Sciences 53 156-161.

Edwards PA \& Ericsson J 1999 Sterols and isoprenoids: signaling molecules derived from the cholesterol biosynthesis pathway. Annual Review of Biochemistry 68 157-185.

Garcia-Roman N, Alvarez AM, Toro MJ, Montes A \& Lorenzo MJ 2001 Lovastatin induces apoptosis of spontaneously immortalized rat brain neuroblasts: involvement of nonsterol isoprenoid biosynthesis inhibition. Molecular and Cellular Neurosciences 17 329-341.

Gould AL, Rossouw JE, Santanello NC, Heyse JF \& Furberg CD 1998 Cholesterol reduction yields clinical benefit: impact of statin trials. Circulation 97 946-952.

Grundy SM 1998 HMG-CoA reductase inhibitors for treatment of hypercholesterolaemia. New England Journal of Medicine 319 24-33.

Guijarro C, Blanco-Colio LM, Massy ZA, O’Donnell MP, Kasiske BL, Keane WF \& Egido J 1999 Lipophilic statins induce apoptosis of human vascular smooth muscle cells. Kidney International Supplement 71 88-91. 
Langtry HD \& Markham A 1999 Fluvastatin: a review of its use in lipid disorders. Drugs 57 583-606.

Linder V, Kim SK, Karas RH, Kuiper GG, Gustafsson JA \& Mendelsohn ME 1998 Increased expression of estrogen receptorbeta mRNA in male blood vessels after vascular injury. Circulation Research 27 224-229.

Makela S, Savolainen H, Avik E, Myllarniemi M, Strauss L, Taskinen E, Gustafsson JA \& Hayry P 1999 Differentiation between vasculoprotective and uterotrophic effects of ligands with different binding affinities to estrogen receptors alpha and beta. PNAS $\mathbf{8}$ 7077-7082.

Messmer UK, Pereda-Fernandez C, Manderscheid M \& Pfeilschifter J 2001 Dexamethasone inhibits TNF-alpha-induced apoptosis and IAP down regulation in MCF-7 cells. British Journal of Pharmacology 133 467-476.

Mikosz CA, Brickley DR, Sharkey MS, Moran TW \& Conzen SD 2001 Glucocorticoid receptor-mediated protection from apoptosis is associated with induction of serine/threonine survival gene, sgk-1. Journal of Biological Chemistry 276 16649-16654.

Newton CJ 1995 Estrogen receptor blockade by the pure antiestrogen, ZM 182780, induces death of pituitary tumour cells. Journal of Steroid Biochemistry and Molecular Biology 55 327-336.

Newton CJ, Drummond N, Burgoyne CH, Speirs V, Stalla GK \& Atkin SL 1999 Functional inactivation of the oestrogen receptor by the antioestrogen, ZM 182780, sensitizes tumour cells to reactive oxygen species. Journal of Endocrinology 161 199-210.

Newton CJ, Bilko D, Pappa S \& Atkin SL 2001 Dexamethasone blocks antioestrogen- and oxidant-induced death of pituitary tumour cells. Journal of Endocrinology 169 249-261.

Ormerod MG 1998 Cell cycle analysis of asynchronous population. Methods in Molecular Biology 91 157-165.

Perez-Sala D \& Mollinedo F 1994 Inhibition of isoprenoid biosynthesis induces apoptosis in human promyelocytic HL-60 cells. Biochemical and Biophysical Research Communications 199 1209-1215.

Perrin D \& Hill BT 2000 Tomorrow's anticancer agents: inhibitors of Ras farnesylation. EXS 89 153-179.

Rowinsky EK, Windle JJ \& Von Hoff DD 1999 Ras protein farnesyltransferase: a strategic target for anticancer therapeutic development. Journal of Clinical Oncology 17 3631-3652.
Sasson R, Tajima K \& Amsterdam A 2001 Glucocorticoids protect against apoptosis induced by serum deprivation, cyclic adenosine $3^{\prime}, 5^{\prime}$-monophosphate and p53 activation in immortalized human granulosa cells: involvement of Bcl-2. Endocrinology 142 802-811.

Scheidegger KJ, Cenni B, Picard D \& Delafontain P 2000 Estradiol decreases IGF-I and IGF-I receptor expression in rat aortic smooth muscle cells. Mechanisms for its atheroprotective effects. Journal of Biological Chemistry 275 38921-38928.

Sebti SM \& Hamilton AD 2000 Farnesyltransferase and geranylgeranyltransferase I inhibitors in cancer therapy: important mechanistic and bench to bedside issues. Expert Opinion on Investigational Drugs 9 2767-2782.

Sinensky M 2000 Recent advances in the study of prenylated proteins. Biochimica et Biophysica Acta 1484 93-106.

Speirs V, Boyle-Walsh E \& Fraser WD 1997 Constitutive coexpression of estrogen and progesterone receptor mRNA in human meningiomas by RT-PCR and response of in vitro cell cultures to steroid hormones. International Journal of Cancer 72 714-719.

Stark WW, Blaskovich MA, Johnson BA, Qian Y, Vasudevan A, Pitt B, Hamilton AD, Sebti SM \& Davies P 1998 Inhibiting geranylgeranylation blocks growth and promotes apoptosis in pulmonary vascular smooth muscle cells. American Journal of Physiology 275 55-63.

Wu JR \& Gilbert DM 2000 Lovastatin arrests CHO cells between the origin decision point and the restriction point. FEBS Letters 3 108-112.

Zhang HH, Kumar S, Barnett AH \& Eggo MC 2001 Dexamethasone inhibits tumour necrosis factor-alpha-induced apoptosis and interleukin-1 beta release in human subcutaneous adipocytes and preadipocytes. Journal of Clinical Endocrinology and Metabolism 86 $2817-2825$.

Zou H, Li Y \& Wang X 1999 An APAF-1 cytochrome c multimeric complex is a functional apoptosome that activates procaspase-9. Journal of Biological Chemistry 274 11549-11556.

Received in final form 13 February 2002

Accepted 19 March 2002 